Article

\title{
Evaluation of Determinants of Food Waste in Family Households in the Greater Porto Area Based on Self-Reported Consumption Practices
}

\author{
Taíse Portugal ${ }^{1}$, Susana Freitas ${ }^{2}$, Luís Miguel Cunha ${ }^{3, * \text { (I) }}$ \\ and Ada Margarida Correia Nunes Rocha ${ }^{4, *(1)}$ \\ 1 Faculty of Nutrition and Food Sciences, University of Porto, 4150180 Porto, Portugal; up201602964@fc.up.pt \\ 2 Departmento de Educação, Comunicação e Marketing, Lipor, 4435-746 Baguim do Monte, Portugal; \\ susana.freitas@lipor.pt \\ 3 GreenUPorto, Department of Geosciences, Environment and Planning, Faculty of Sciences, \\ University of Porto, 4485-646 Vila do Conde, Portugal \\ 4 LAQV-REQUIMTE/GreenUPorto, Faculty of Nutrition and Food Sciences, University of Porto, \\ 4150180 Porto, Portugal \\ * Correspondence: lmcunha@fc.up.pt (L.M.C.); adarocha@fcna.up.pt (A.M.C.N.R.)
}

Received: 30 September 2020; Accepted: 20 October 2020; Published: 22 October 2020

check for updates

\begin{abstract}
Despite food waste occurring along the entire food supply chain, a significant proportion occurs in domestic settings. Large quantities of domestic food waste have been attributable to consumer behaviors during buying, cooking, consumption, and disposal. The main objective of this research was to understand the major determinants of household food waste from families in the north of Portugal. A convenience sample was used, which was drawn from households in the Greater Porto Area. Data were collected through a self-reported questionnaire that included three groups of structured questions related to perceived behavior and attitudes towards food consumption, leftover usage, and food waste. Exploratory data analysis was used to identify underlying dimensions. No relationships were found between socio-demographic data and food waste, buying behavior, or destination/use of leftovers. The majority of the participants reported a high level of planning of their grocery shopping. Fruits and vegetables presented the highest frequency of consumption, followed by sources of carbohydrates and sources of proteins. The storage of cooked food from different food groups presented a single factor, grouping the majority of the individual food leftovers, going from fruits and vegetables to sources of carbohydrates and proteins. The reported levels of wastage of the different food products were grouped into three dimensions: waste of vegetables, waste of protein sources, and waste of sources of carbohydrates. Waste of precooked foods emerged as an independent item, and it was the individual item with the highest frequency. The families studied reported a positive attitude concerning buying, consumption, and wastage, revealing a particular awareness of food waste and its social and environmental impact.
\end{abstract}

Keywords: household food waste; planning routines; shopping routines; food practices

\section{Introduction}

The postmodern society is a consumer society where 'having' becomes more important than 'being' $[1,2]$. In both rich and poor countries, statistics indicate that waste increases together with the increase in consumption [3]. The modern society faces a social drama as a result of the dimension of food waste, which has severe impacts on the economy and environment, while millions of people are starving all over the world [4]. 
According to the Food and Agriculture Organization (FAO), approximately one-third of the food produced for human consumption in the world is lost, with about 1300 million tons being lost or wasted [5]. Focusing on the European Union (EU), this figure totals $76 \mathrm{~kg}$ per person per year, representing approximately $45 \%$ of the total food waste in the entire supply chain, excluding agricultural production. In view of this situation, the European Commission has established the target of reducing food waste by one-half by 2020 throughout the EU [6].

The European Parliament defined food waste as "all food, defined as: any substance or product, whether processed, partially processed or unprocessed, intended to be, or reasonably expected to be ingested by humans, that has become waste" [7].

The reasons for food waste are variable, including inefficient storage and transportation practices, adoption of very tight expiration dates, and promotions that encourage people to buy greater quantities [7,8].

Despite food waste occurring along the entire food supply chain, significant proportions occur in domestic settings [9]. Household food waste is largely uncontrolled despite numerous initiatives that have been implemented to reduce it. Large quantities of domestic food waste have been attributable to consumer behaviors during buying, cooking, consumption, and disposal [10].

In 2015, in a survey developed in Portugal by the consumer defense association Defesa do Consumidor (DECO) with 1725 consumers, high amounts of food waste were found. More than 50\% of respondents reported throwing away food with expired dates. The main reasons referred to were related to the difficulty of understanding labels [11].

Food waste is a very widespread phenomenon that is also found in families who are generally aware of this problem and make resolutions to avoid this kind of behavior. In Portugal, limited information is available concerning household food waste.

The main objective of this research was to better understand the major determinants of household food waste from families living in eight municipalities in the north of Portugal, near Lipor, which is the Intermunicipal Waste Management Service. It was also intended to characterize the food waste in terms of reasons to waste, most frequently wasted foods, and buying patterns, as well as to identify the most common destinations of leftovers. This association manages about 500 thousand tons of urban residues produced by about 1 million inhabitants yearly [12].

\section{Materials and Methods}

\subsection{Sample Description}

A convenience sample was used, drawn from households in the area surrounding Lipor, corresponding to eight municipalities in the Greater Porto Area (Espinho, Gondomar, Maia, Matosinhos, Porto, Póvoa de Varzim, Valongo, Vila do Conde) that were registered in Lipor's database, including people registered and living nearby and that usually attended courses and activities of the organization. Data were exported for verifications during September 2017. Every month, new members were included. The selected database included 27,830 entries; nevertheless, only 10,484 had an email contact. From those, only 8785 were validated to receive the questionnaire due to incomplete questionnaire filling and limitations arising from the European Regulation on Data Protection. Later, the academic community of the University of Porto was also included to enlarge the recruitment base and compensate for the lack of participation.

\subsection{Data Collection}

Data were collected through a self-reported questionnaire. The questionnaire included 22 questions and was organized into three groups (see Appendix A for the attitudinal and behavioral questions).

The group "Shopping and consumption" included four questions to identify buying and consumption patterns of the household. This group included four questions, each with several items: one multiple choice, describing the place of purchase; and three frequency questions, with 
answers given using seven-point scales, including shopping behaviors (seven items evaluated on an anchored scale, with answers ranging from (1) Never to (7) On every purchase), an abbreviated food frequency questionnaire (13 items answered on a fully described scale, with answers ranging from (1) Never or less then 1 time/month to (7) More than once a day), and a food leftovers frequency questionnaire (identical set of 13 items evaluated on an anchored scale, with answers ranging from (1) Never to (7) On every consumption moment). The second group, "Food and food waste habits", included four questions to evaluate additional behaviors related to leftovers and food waste, including the usual destination of leftovers (five items evaluated on an anchored scale, with answers ranging from (1) Never to (7) On every consumption moment), a food waste frequency questionnaire (identical set of 13 items evaluated on an anchored scale, with answers ranging from (1) Never to (7) On every consumption moment), and the reasons for food waste (five items evaluated on an anchored scale, with answers ranging from (1) Totally disagree to (7) Totally agree). The third group included sociodemographic data.

The first draft of the questionnaire was developed and tested on a group of individuals of different ages and education levels who worked at Lipor or in the Faculty of Food Sciences and Nutrition, University of Porto, to evaluate the clarity and understanding of the questionnaire. The final questionnaire, entitled "Evaluation of consumption habits", was applied using the software "Google Forms".

In the first phase, the link for this questionnaire was sent by email to 8000 people between the 9th and the 31st of January 2018. Questionnaires were addressed to family members with greater responsibility in meal preparation. Due to the low number of answers, it was sent by dynamic email to the members of the University of Porto academia, and was available between the 10th April and the 1st of May 2018.

Free and informed consent was obtained from all participants after the study was explained, and both anonymity and confidentiality of the data were guaranteed. This study respected all the ethical principles and recommendations of the Helsinki Declaration and the World Health Organization (WHO).

\subsection{Data Analysis}

The theoretical distributions of the variables were analyzed using means, deviations, the histogram of distribution, and the Shapiro-Wilk test.

Exploratory factor analysis (EFA) was performed over each set of questions. In the EFA, valid items were extracted, considering only those with factorial loads above 0.5. The EFA was performed with varimax rotation. A Kaiser-Meyer-Olkin (KMO) value greater than 0.60 was used to verify the adequacy. Consistency of the built factors was measured using Cronbach's alpha.

Factors emerging from the food waste frequency data were adjusted using generalized linear models (GLM) to determine which variables were associated with the food waste factors, with multiple linear models being developed. The independent variables in each model were those variables that presented a Pearson correlation coefficient greater than 0.30 and differences in Student's t-test. Homoscedasticity and model fit were evaluated by residual analysis and the Chi-squared test.

The tests were conducted using the statistical program IBM SPSS Statistics v.24.

\section{Results and Discussion}

A total of 438 fully completed questionnaires were collected. Most respondents were women (Table 1), which was expected, since, in Portugal, the majority of household gatekeepers are women. A high predominance of respondents were aged between 30 and 49 years (38.4\%), representing the most prevalent age group in Portugal according to the available data [13]. The majority of respondents have higher education $(74.7 \%)$, which does not represent the reality of the Portuguese population according to National Statistics, which state that in this age group, only around $27 \%$ of the population has a higher degree level [14]. 
Table 1. Socio-demographic characterization of the respondents $(n=438)$.

\begin{tabular}{ccc}
\hline Characteristics & $n$ & $\%$ \\
\hline Sex & 336 & 76.7 \\
Female & 102 & 23.3 \\
Male & & \\
Age group & 160 & 36.5 \\
30-29 years old & 168 & 38.4 \\
$\geq$ 50 years old & 110 & 25.1 \\
Level of education & & \\
Without a higher degree & 111 & 25.3 \\
With a higher degree & 327 & 74.7 \\
Level of education of main family provider & & 33.8 \\
\hline Without a higher degree & 147 & 66.2 \\
With a higher degree & 288 & \\
Household per capita income & & 50.7 \\
\hline <2018's MNS * & 206 & 49.3 \\
$\geq 2018^{\prime}$ s MNS & 200 & 77.9 \\
Has car & & 22.1 \\
Yes & 338 & 75.3 \\
Type of home & 96 & 24.6 \\
\hline Own & &
\end{tabular}

${ }^{*}$ MNS: Minimum national salary for Portugal.

Nevertheless, $50.7 \%$ of the families have an average per capita income below the minimum national salary for Portugal of 580 EUR. The family income values were used based on the national minimum wage for the year 2018. Regarding the type of housing, $75.3 \%$ said they had their own housing and $77.9 \%$ of the respondents had a car (Table 1 ).

No relationships were found between socio-demographic data of our respondents and food waste, buying behavior, or destination of leftovers $(p>0.01)$. On the contrary, Baptista et al. [15] found a relationship between social characteristics and household waste in Portugal: Families with children waste more food; nevertheless, a tendency for reducing food waste with age was found [15]. Similarly, according to the research developed by Evans 2012 [16], having children is associated with larger amounts of waste in total.

In a study on the attitudes of Greek household members regarding food waste generation [17], a positive attitude towards food waste prevention was revealed, driven by financial necessity and a high degree of misconception of food labeling. It was found that the higher the educational level, the better the reported behavior towards food waste prevention, as a straightforward outcome of the correct comprehension of food labels. In addition, semi-urban and middle-income households make better use of the refrigerator and have better management of leftovers by cooking them, respectively.

In our study, $82 \%$ of households make purchases at large department stores (hypermarkets, supermarkets). Only $1 \%$ of respondents usually buy at organic stores, which is in line with data from various studies that have been reported, highlighting that food is mainly bought from major supermarket chains and that only a small percentage buys from smaller stores $[10,18,19]$.

The characterization of buying behavior was divided into three dimensions, though only one of the dimensions presented adequate consistency $(\alpha>0.5)$, corresponding to "Planning". The majority of the participants reported a high level of planning of their grocery shopping (Table 2). 
Table 2. Buying behavior of respondents $(n=438)$ evaluated over a seven-point anchored scale *

\begin{tabular}{|c|c|c|c|}
\hline $1 .^{*}$ & $\begin{array}{c}\text { Behavior at buying occasions (explained variance, } \\
\text { Cronbach's alpha }(\alpha) \text { ), KMO }=0.608\end{array}$ & Mean \pm SD & Loadings \\
\hline & Factor 1-Planning (var: $28.3 \% ; \alpha: 0.746$ ) & $5.5 \pm 1.1$ & \\
\hline & Buying with shopping list & $5.2 \pm 1.6$ & 0.898 \\
\hline & Buying without shopping list (reversed scale) & $6.0 \pm 1.1$ & 0.874 \\
\hline & $\begin{array}{c}\begin{array}{c}\text { Evaluation of contents of refrigerator and pantry } \\
\text { before shopping }\end{array} \\
\text {. }\end{array}$ & $5.4 \pm 1.5$ & 0.623 \\
\hline & Factor 2-Promotions (var: 17.7\%; $\alpha: 0.224$ ) & $4.1 \pm 1.2$ & \\
\hline & Preference for a specific product or brand & $4.3 \pm 1.5$ & 0.749 \\
\hline & Purchases based on vouchers and promotions & $3.9 \pm 1.7$ & 0.635 \\
\hline & Factor 3 -Convenience (var: $17.6 \% ; \alpha: 0.389$ ) & $2.3 \pm 1.0$ & \\
\hline & Purchase of take-away meals & $2.4 \pm 1.3$ & 0.862 \\
\hline & Get trendy foods and meals & $2.1 \pm 1.2$ & 0.647 \\
\hline \multirow[t]{16}{*}{2.} & $\begin{array}{l}\text { Food buying frequency (explained variance, } \\
\text { Cronbach's alpha }(\alpha)), \text { KMO }=0.713 \text {. }\end{array}$ & Mean \pm SD & Loadings \\
\hline & $\begin{array}{c}\text { Factor 1-Fruits and vegetables (var: } 21.3 \% ; \alpha \text { : } \\
0.714 ; \text { ) }\end{array}$ & $5.4 \pm 1.0$ & \\
\hline & Vegetables and salads & $5.7 \pm 1.4$ & 0.787 \\
\hline & Pulses (dried and fresh) & $4.6 \pm 1.5$ & 0.715 \\
\hline & Fruits & $6.2 \pm 1.2$ & 0.691 \\
\hline & Soup & $5.3 \pm 1.6$ & 0.661 \\
\hline & $\begin{array}{c}\text { Factor 2-Carbohydrate suppliers (var: } 19.6 \% ; \alpha \text { : } \\
\text { 0.657) }\end{array}$ & $5.1 \pm 1.0$ & \\
\hline & Rice/pasta & $5.3 \pm 1.3$ & 0.809 \\
\hline & Potatoes & $4.4 \pm 1.4$ & 0.755 \\
\hline & Bread & $5.7 \pm 1.4$ & 0.648 \\
\hline & Factor 3-Sources of proteins (var: $14.6 \% ; \alpha: 0.548$ ) & $4.6 \pm 0.9$ & \\
\hline & Eggs & $3.9 \pm 1.1$ & 0.655 \\
\hline & Seafood (fish and shellfish) & $4.1 \pm 1.2$ & 0.651 \\
\hline & Meat (poultry, pork, and beef) & $4.8 \pm 1.5$ & 0.616 \\
\hline & Dairy products (milk, yogurt, and cheese) & $5.6 \pm 1.7$ & 0.516 \\
\hline & Precooked food & $2.1 \pm 1.0$ & \\
\hline \multirow[t]{14}{*}{3.} & $\begin{array}{l}\text { Frequency of storage of cooked food (explained } \\
\text { variance, Cronbach's alpha }(\alpha)), \mathrm{KMO}=0.915\end{array}$ & Mean \pm SD & Loadings \\
\hline & Factor 1-Keep leftovers (var: $55.9 \% ; \alpha: 0.915$ ) & $5.5 \pm 1.4$ & \\
\hline & Pasta/Rice & $5.9 \pm 1.5$ & 0.807 \\
\hline & Bread & $6.0 \pm 1.6$ & 0.793 \\
\hline & Pulses (dried and fresh) & $5.5 \pm 1.9$ & 0.780 \\
\hline & Seafood (fish and shellfish) & $5.2 \pm 2.0$ & 0.773 \\
\hline & Meat (poultry, pork, and beef) & $5.7 \pm 1.8$ & 0.765 \\
\hline & Soup & $6.2 \pm 1.4$ & 0.740 \\
\hline & Fruit & $5.4 \pm 1.2$ & 0.740 \\
\hline & Potatoes & $5.0 \pm 2.1$ & 0.739 \\
\hline & Vegetables and salads & $5.2 \pm 2.1$ & 0.737 \\
\hline & Eggs & $4.6 \pm 2.4$ & 0.675 \\
\hline & Dairy products (milk, yogurt, and cheese) & $5.4 \pm 2.2$ & 0.663 \\
\hline & Precooked food & $3.3 \pm 2.4$ & \\
\hline \multirow[t]{7}{*}{4.} & $\begin{array}{l}\text { Behavior concerning leftover usage (explained } \\
\text { variance, Cronbach's alpha }(\alpha) \text { ), KMO = 0.624 }\end{array}$ & Mean \pm SD & Loadings \\
\hline & Factor 1-Use of leftovers (var $54.6 \% ; \alpha: 0.576)$ & $4.9 \pm 1.2$ & \\
\hline & To prepare new culinary items & $4.7 \pm 1.6$ & 0.783 \\
\hline & Freeze for another occasion & $4.4 \pm 1.8$ & 0.736 \\
\hline & Eat on the next day & $5.7 \pm 1.2$ & 0.699 \\
\hline & Throw away & $2.2 \pm 1.2$ & \\
\hline & Animal feed & $2.6 \pm 2.0$ & \\
\hline \multirow[t]{8}{*}{5.} & $\begin{array}{c}\text { Factors related with food waste (explained } \\
\text { variance, Cronbach's alpha }(\alpha) \text { ), KMO = } 0.792\end{array}$ & Mean \pm SD & Loadings \\
\hline & $\begin{array}{l}\text { Factor } 1-\text { No purchasing planning (var: } 41.7 \% ; \alpha \text { : } \\
0.792 \text { ) }\end{array}$ & $2.3 \pm 1.4$ & \\
\hline & Excess purchase due to promotion & $2.1 \pm 1.6$ & 0.882 \\
\hline & No shopping list & $2.1 \pm 1.6$ & 0.875 \\
\hline & No control of stored items at home & $2.7 \pm 1.9$ & 0.659 \\
\hline & $\begin{array}{l}\text { Factor 2-No planning during cooking (var: } 30 . \\
\qquad 9 \% ; \alpha: 0.546)\end{array}$ & $3.5 \pm 1.7$ & \\
\hline & Excess food is made for meal & $3.7 \pm 2.2$ & 0.850 \\
\hline & Foods with short shelf life & $3.2 \pm 1.9$ & 0.727 \\
\hline
\end{tabular}

* Anchored scale: (1) with answers ranging from 1 (Never) to 7 (On every purchase); (2) a fully described scale, with answers ranging from 1 (Never or less than 1 time/month) to 7 (More than once a day); ( 3 and 4 ) with answers ranging from 1 (Never) to 7 (On every consumption moment); (5) with answers ranging from 1 (Totally disagree) to 7 (Totally agree). 
Careful planning of grocery shopping was reported by several others as an effective strategy to prevent over-purchasing and, ultimately, food waste $[10,18,20]$. Planning includes using a shopping list, performing meal planning, and checking the refrigerator and store room before shopping.

Consumed foods were grouped into three types: fruits and vegetables, sources of carbohydrates, and sources of proteins, the first presenting the highest frequency of consumption, followed by sources of carbohydrates and sources of proteins. Additionally, the participants reported low frequency of consumption of precooked food.

The storage of cooked food presented a single factor, grouping the majority of the individual food leftovers going from fruits and vegetables to sources of carbohydrates and proteins.

In general, participants presented a high level of leftover storage with the exception of precooked food. The observed behavior of storing leftovers is in agreement with data published by Schanes et al. in 2018, who reported a stronger motivation to reduce food waste, pointing to financial concerns rather than environmental or social concerns [21]. On the other hand, the behavior regarding precooked food may indicate a higher level of the confidence that consumers have in home-cooked items compared to out-of-home prepared food. Households frequently have difficulties in assessing the durability of leftovers and tend to be concerned about their safety. Concerns about foodborne illnesses coupled with the desire to eat fresh foods are decisive reasons for wasting foods [22-24].

As already reported by others, health concerns are usually associated with the increase of the amount of waste of highly perishable food, such as meat, fish, and dairy products, due to the knowledge of the increased risks and consequences of consumption of such products if spoiled [25].

Generally, there was a high frequency of use of leftovers, particularly to be eaten on the following day, in line with the high frequency of use of meals taken from home, mainly for lunchtime meals (Direção Geral de Saúde, 2020) [26], with very low frequency of disposal of leftovers and use for pet feed. In this study, pet ownership was not evaluated, so it was not possible to correlate these data.

On the contrary, some authors reported that eating leftovers is not well accepted due to an aversion to reheating leftovers, as they are considered less nutritious and less fresh, and also because it was found to be boring to eat the same food twice $[27,28]$.

The main perceived reasons for food waste were divided into two main factors, related to the lack of planning during purchase and the lack of planning during cooking, both presenting a low frequency-particularly the lack of purchase planning-which is in accordance with the buying behavior data. Eighty percent of the respondents justify the occurrence of leftovers with a consumption lower than expected, while $48 \%$ reported cooking higher quantities than necessary, with $36 \%$ of the participants indicating both reasons. It is noteworthy that less than $20 \%$ associated leftovers with the short shelf life of some items and even less with the low sensory appeal of the meals (Table 3).

Table 3. Most frequent reasons for leftovers at households.

\begin{tabular}{ccc}
\hline Most Frequent Reasons & $\boldsymbol{n}$ & $\mathbf{\%}$ \\
\hline Consumption lower than expected * $^{*}$ & 350 & 79.9 \\
Over-cooking * & 212 & 48.4 \\
Short shelf life & 86 & 19.6 \\
Meals' low acceptability & 58 & 13.2 \\
Other & 44 & 10.0 \\
\hline
\end{tabular}

${ }^{*}$ A total of $159(36 \%)$ indicated two reasons.

According to several studies, consumers show difficulties while estimating portion sizes for the family meal, resulting in overcooking and promoting leftovers that frequently are spoiled and wasted [20]. On the other hand, families also reported a difficulty to predict children's appetite and the number of family members eating at home, resulting in leftovers of non-consumed food [21,29].

In Central Europe, the most frequently cited reasons for throwing the food away reported by Simunek et al. (2015) were similar to our findings, nevertheless in a different order. The first reason was 
that the food was spoilt, followed by food having been past the expiration date, an excessive amount of food having been purchased, and unpalatable food, as well as "other reasons" in the lower rank [30].

According to the research of Abeliots et al. (2015), better cooking skills are associated with better handling of leftovers and improved food waste prevention; the increased awareness of food waste is also a strong motivational factor for food waste reduction [31].

Reported waste frequency of the different food products was grouped into three dimensions: waste of vegetables, waste of protein sources, and waste of sources of carbohydrates. Waste of precooked foods emerged as an independent item, and was the individual item with the highest frequency.

Differences in frequency of food disposal as waste between food categories-namely, the lower values for the different sources of protein (Table 4)-have been attributed by others to the awareness of consumers concerning the higher environmental impact of producing meat and fish compared to other food categories, as well as to the higher cost of these. Simunek et al. (2015), in a research project developed in Central Europe [30], found that the food category most likely to be discarded was milk and dairy products, followed by fresh vegetables and mushrooms, then bread and cereals, unconsumed pre-processed foods, fruits and nuts, smoked meat, and, finally, food scraps from the plate. Contrarily, raw meat, fish, canned food, and "other" foods (such as sweets and snacks) did not appear in the food waste for any of the respondents.

Table 4. Analysis of the frequencies of types of wasted food. $(n=438)$.

\begin{tabular}{|c|c|c|c|}
\hline 5. & $\begin{array}{l}\text { Factors related with type of food waste (explained } \\
\text { variance, Cronbach's alpha }(\alpha)), \mathrm{KMO}=0.885\end{array}$ & Mean \pm SD & Loadings \\
\hline & Factor $1-$ Waste of vegetables (var: $23.7 \% ; \alpha$ : 0.758 ) & $2.0 \pm 0.9^{b}$ & \\
\hline & Vegetables & $2.4 \pm 1.5$ & 0.764 \\
\hline & Dried and Fresh Pulses & $1.7 \pm 1.1$ & 0,665 \\
\hline & Fruit & $2.1 \pm 1.1$ & 0.640 \\
\hline & Soup & $1.8 \pm 1.0$ & 0.601 \\
\hline & $\begin{array}{c}\text { Factor } 2-\text { Waste of protein sources (var: } 21.9 \% ; \alpha \text { : } \\
0.793 \text { ) }\end{array}$ & $1.8 \pm 0.8^{a}$ & \\
\hline & Dairy products & $1.9 \pm 1.1$ & 0.751 \\
\hline & Fish & $1.8 \pm 1.1$ & 0.714 \\
\hline & Eggs & $1.6 \pm 1.1$ & 0.689 \\
\hline & Meat & $1.7 \pm 1.0$ & 0.551 \\
\hline & $\begin{array}{l}\text { Factor 3-Waste of sources of carbohydrates (var: } \\
\qquad 17.4 \% ; \alpha: 0.703 \text { ) }\end{array}$ & $2.0 \pm 0.9^{b}$ & \\
\hline & Potato & $2.0 \pm 1.1$ & 0.810 \\
\hline & Bread & $2.0 \pm 1.2$ & 0.628 \\
\hline & Pasta & $2.0 \pm 1.2$ & 0.510 \\
\hline & Pre-cooked food & $2.5 \pm 1.9^{b}$ & \\
\hline
\end{tabular}

${ }^{a}, b$ : homogeneous groups according to the Wilcoxon test at a $95 \%$ confidence level.

From the models in Table 5, wastage of vegetable products is mainly due to the lack of planning during purchase and buying by convenience, while it is inversely correlated to the consumption of vegetables and precooked meals. 
Table 5. Multiple linear models describing the behavior of respondents concerning food waste of different groups of foods based on different determinants of food waste.

\begin{tabular}{|c|c|c|c|c|}
\hline Model 1 & $\begin{array}{c}\text { Waste of vegetables, food habits, and } \\
\text { behavior } \\
R_{\text {adj }}^{2}=0.190\end{array}$ & Coefficient & SD & $p$-value \\
\hline & Throwing away & 0.193 & 0.034 & 0.000 \\
\hline & Lack of buying planning & 0.084 & 0.027 & 0.002 \\
\hline & Consumption of vegetables & -0.124 & 0.038 & 0.001 \\
\hline & Purchasing by convenience & 0.139 & 0.041 & 0.001 \\
\hline & Precooked meal & -0.038 & 0.017 & 0.023 \\
\hline \multirow[t]{6}{*}{ Model 2} & $\begin{array}{c}\text { Waste of protein sources, food habits, and } \\
\text { behavior } \\
\qquad \mathbf{R}_{\text {adj }}^{2}=0.196\end{array}$ & Coefficient & SD & $p$-value \\
\hline & Throwing away & 0.185 & 0.033 & 0.000 \\
\hline & Lack of cooking planning & 0.070 & 0.022 & 0.002 \\
\hline & Keeping leftovers & -0.070 & 0.027 & 0.010 \\
\hline & Purchasing by convenience & 0.097 & 0.038 & 0.011 \\
\hline & Animal feeding & 0.038 & 0.019 & 0.042 \\
\hline \multirow[t]{5}{*}{ Model 3} & $\begin{array}{l}\text { Waste of carbohydrate sources, food habits, } \\
\text { and behavior } R^{2}{ }^{2} \text { dj }=0.228\end{array}$ & Coefficient & SD & $p$-value \\
\hline & Throwing away & 0.273 & 0.035 & 0.000 \\
\hline & Lack of cooking planning & 0.085 & 0.024 & 0.000 \\
\hline & Precooked meal & -0.036 & 0.017 & 0.032 \\
\hline & Purchasing by convenience & 0.088 & 0.041 & 0.034 \\
\hline
\end{tabular}

Wastage of sources of protein is directly related to a lack of cooking planning, purchasing by convenience, and pet feeding, while it is inversely correlated to the use of leftovers.

Wastage of carbohydrate sources is related to a lack of cooking planning and purchasing by convenience, and it is indirectly correlated to the consumption of precooked meals.

According to the research by Visschers et al. (2016), families with children waste more food in total, namely fruits and vegetables, bakery products, and starches. Protein sources, ready-to-eat products, and dairy products seem to be the exception, probably due to consumers' appreciation of those products or to the perceived related price and the intention not to discard them [25].

Overall, these models identifying the major determinants of food waste for the different food groups are somehow low, but are significant and in line with previous studies.

There is a large number of behaviors that can have a positive impact on food waste generation and, consequently, on prevention of food waste [32]. Such behaviors include meal planning, cupboard and refrigerator checking, shopping list making, adequate storage of food items, use of food leftovers, adjust cooking amounts of food, and attention to expiration date labels [33].

It was found that respondents that do not plan purchases and that buy convenient foods waste more food. On the other hand, keeping precooked food and the consumption of vegetables are inversely associated with the amount of food waste (Table 5).

The variables that contribute the most to the waste of protein sources are lack of cooking planning, purchasing by convenience, throwing foods away, and feeding pets. The higher the amount of leftovers stored, the lower the waste of protein sources.

Carbohydrate sources are less wasted when the amount of precooked food increases. The variables of throwing away food, the lack of cooking planning, and purchasing by convenience contribute to a greater waste of carbohydrate sources.

The knowledge of both 'expiration date' or 'best used before' food labels should be improved among families. In addition, the cooking skills of consumers should also be improved, since this will enable a reduction of food waste through better handling of leftovers.

The most common strategies for reducing food waste include adjusting the quantity of food purchased to the size of household, better planning of food consumption with respect to the expiration date, and choosing high-quality foods with longer expiration dates bought from small retailers. 


\section{Conclusions}

The sample of families studied reported a positive attitude concerning buying, consumption, and wastage, revealing a particular awareness of food waste and its social and environmental impact. These families have a privileged access to information, as they live near Lipor and have several activities in these areas, such as training courses, leaflets, cooking classes, easy access to recycling and reusing facilities, and study visits. At the same time, this is the main limitation of this study, as it impairs the generalization of the results, as there is some sample bias.

Author Contributions: Conceptualization, A.M.C.N.R. and S.F.; methodology, A.M.C.N.R. and L.M.C., formal analysis, A.M.C.N.R. and L.M.C.; investigation, T.P.; writing-original draft preparation, T.P.; writing-review and editing, A.M.C.N.R. and L.M.C.; funding, A.M.C.N.R. and L.M.C.; supervision, A.M.C.N.R. All authors have read and agreed to the published version of the manuscript.

Funding: This research was supported by national funds through FCT (Foundation for Science and Technology) within the scope of UIDB/05748/2020 and UIDP/05748/2020. Authors L.M. Cunha and A. Rocha acknowledge support from the project AgriFood XXI-NORTE-01-0145-FEDER-000041, financed through Norte2020, CCDR-N, Portugal2020, and the European Fund for Regional Development.

Conflicts of Interest: The authors declare no conflict of interest.

\section{Appendix A}

This section presents the wording of the attitudinal and behavioral questions included in the questionnaire. The original text in Portuguese is presented in italics.

\section{"Shopping and consumption"}

Frequency of shopping behaviors ( 7 items evaluated on an anchored scale, with answers ranging from (1) Never to (7) On every purchase)/Com que frequência tem os seguintes comportamentos na compra de alimentos? (Sendo que "1" refere-se a "nunca" e "7" a "sempre que compra"):

- Buying with a shopping list/Compra com lista previamente elaborada

- Purchases based on vouchers and promotions/Compra em função dos vales de compra ou outras promoções que possui

- Preference for a specific product or brand/Preferência por produto especifico ou marca

- Evaluation of contents of the refrigerator and pantry before shopping/Antes de efetuar as compras, avalia o que existe no frigorífico e na despensa

- Buying without a shopping list/Compra sem preparar previamente a lista

- Purchase of take-away meals/Adquire refeições do take-away

- Getting trendy foods and meals/Adquire alimentos e refeições que estão na "moda"

Abbreviated food frequency questionnaire (13 items answered on a fully described scale, with answers ranging from (1) Never or less than 1 time/month to (7) More than once a day)/Com que frequência consome os seguintes alimentos? (1) Nunca ou $<1 \times$ mês; (2) $1-3 \times$ por mês; (3) 1 x por semana; (4) 2-4 x por semana; (5) 5-6 x por semana; (6) 1 x por dia; (7) + de $1 \times$ por dia).

- $\quad$ Fruits/Fruta

- Seafood (fish and shellfish)/Pescado (peixe, moluscos)

- Vegetables and salads/Hortícolas/saladas

- Pulses (dried and fresh)/Leguminosas secas/frescas

- Eggs/Ovos

- Soup/Sopa

- Dairy products (milk, yogurt, and cheese)/Laticínios (leite, queijo, iogurte)

- Rice/pasta/Massa/Arroz

- Potatoes/Batata 
- $\quad$ Bread/Pão

- Meat (poultry, pork, and beef)/Carne (aves, suíno, bovino)

- Fats (Olive oil/vegetable oils)/Gorduras (azeite/óleo)

- Precooked food/Comida pré confecionada

A food leftover frequency questionnaire (identical set of 13 items evaluated on an anchored scale, with answers ranging from (1) Never to (7) On every consumption moment)/Indique com que frequência costuma guardar as sobras dos seguintes alimentos (Sendo que " 1 " refere-se a "nunca" $e$ " 7 " a "sempre que consome").

\section{"Food and food waste habits"}

Additional behaviors related to leftovers and food waste, including the usual destination of leftovers (5 items evaluated on an anchored scale, with answers ranging from (1) Never to (7) On every consumption moment)/Indique a frequência com que realiza estes comportamentos quando tem sobras de alimentos ou refeições: (Sendo que "1" refere -se a "nunca" e "7" a "sempre que consome").

- Preparing new culinary items/Elabora novas preparações culinárias

- Throwing away/Deita para o lixo

- Feeding animals/Dá aos animais

- Freezing for another occasion/Congela para outra ocasião

- $\quad$ Eating on the next day/Consome no dia seguinte

Most frequent reasons for leftovers in households (check all that apply)/Escolha os motivos mais frequentes para ocorrerem sobras na sua residência (Marque todas que se aplicam).

A food waste frequency questionnaire (identical set of 13 items evaluated on an anchored scale, with answers ranging from (1) Never to (7) On every consumption moment)/Com que frequência costuma deitar fora os seguintes alimentos: (Sendo que "1"refere-se a "nunca" e "7" a "sempre que consome").

Attitudes towards reasons for food waste (5 items evaluated on an anchored scale, with answers ranging from (1) Totally disagree to (7) Totally agree)/Indique o seu grau de concordância com as seguintes afirmações. No meu agregado familiar ocorre desperdício alimentar quando: (Sendo que "1" refere-se a "discordo plenamente" e "7"a "concordo plenamente").

- Excess food is made for meals/Se confecionam alimentos em excesso para a refeição

- No control of stored items at home/Não se controla o que ainda existe em casa (despensa/frigorífico)

- Foods with short shelf-life/Se os alimentos apresentam um prazo de validade muito curto

- No shopping list/Ausência de lista para a realização de compras

- Excess purchase due to promotion/Se compra em excesso em virtude da promoção

\section{References}

1. Bauman, Z. A Cultura do Lixo; Desperdiçadas, E.V., Zahar, J., Eds.; Zahar: Rio de Janeiro, Brazil, 2004; pp. 117-164.

2. Baudrillard, J. The Consumer Society: Myths and Structures; Sage: Thousand Oaks, CA, USA, 2016.

3. Goulart, R. Desperdício de Alimentos: Um Problema de Saúde Pública. Revista Integração 2008, 54, 285.

4. FAO. Food Wastage Footprint: Impacts on Natural Resources; FAO: Rome, Italy, 2013.

5. Gustavsson, J.; Cederberg, C.; Sonesson, U.; Van Otterdijk, R.; Meybeck, A. Global Food Losses and Food Waste; FAO: Rome, Italy, 2011.

6. Monier, V.; Mudgal, S.; Escalon, V.; O'Connor, C.; Gibon, T.; Anderson, G.; Montoux, H.; Reisinger, H.; Dolley, P.; Ogilvie, S. Preparatory Study on Food Waste Across EU 27; European Commission: Brussels, Belgium, 2010.

7. Agência Portuguesa do Ambiente. Redução do Desperdício Alimentar. 2014. Available online: http://www. apambiente.pt/index.php?ref=16\&subref=84\&sub2ref=106\&sub3ref=273 (accessed on 20 August 2020).

8. European Food Information Council. Fruit and Vegetable Consumption in Europe-Do Europeans Get Enough? EUFIC: Brussels, Belgium, 2012. 
9. Ambler-Edwards, S.; Bailey, K.S.; Kiff, A.; Lang, T.; Lee, R.; Marsden, T.K.; Simons, D.W.; Tibbs, H. Food Futures: Rethinking UK Strategy; A Chatham House Report; Chatham House: London, UK, 2009.

10. Farr-Wharton, G.; Fot, M.; Choi, J. Identifying factors that promote consumer behaviours causing expired domestic food waste. J. Consum. Behav. 2014, 13, 393-402. [CrossRef]

11. DECO. Preço Determina Escolhas do Consumidor. 2015. Available online: http://www.decojovem.pt/ biblioteca/combateaodesperdicioalimentar/ (accessed on 30 July 2020).

12. Instituto Nacional de Estatística. Statistical Yearbook of Portugal 2016; Instituto Nacional de Estatística: Lisboa, Portugal, 2017.

13. Instituto Nacional de Estatística. Censos 2011. Available online: http://www.censos.ine.pt (accessed on 10 September 2020).

14. Anuário Estatístico de Portugal. 2019. Available online: https://www.ine.pt/xportal/xmain?xpid= INE\&xpgid=ine_publicacoes\&PUBLICACOESpub_boui=444301590\&PUBLICACOEStema=55480\& PUBLICACOESmodo=2 (accessed on 30 July 2020).

15. Baptista, P.; Campos, I.; Vaz, S. Do Campo ao Garfo: Desperdício Alimentar Em Portugal, 1st ed.; Cestras: Lisboa, Portugal, 2012.

16. Evans, D. Beyond the throwaway society: Ordinary domestic practice and a sociological approach to household food waste. Sociology 2012, 46, 41-56. [CrossRef]

17. Abeliotis, K.; Lasaridi, K.; Chroni, C.J.W.M. Research, attitudes and behaviour of Greek households regarding food waste prevention. J. Waste Manag. 2014, 32, 237-240.

18. Parizeau, K.; von Massow, M.; Martin, R.J.W.M. Household-Level dynamics of food waste production and related beliefs, attitudes, and behaviours in Guelph, Ontario. Waste Manag. 2015, 35, 207-217. [CrossRef] [PubMed]

19. Yildirim, H.; Capone, R.; Karanlik, A.; Bottalico, F.; Debs, P.; El Bilali, H. Food wastage in Turkey: An exploratory survey on household food waste. Nutr. Res. 2016, 4, 483-489.

20. Secondi, L.; Principato, L.; Laureti, T. Household food waste behaviour in EU-27 countries: A multilevel analysis. Food Policy 2015, 56, 25-40. [CrossRef]

21. Schanes, K.; Dobernig, K.; Gözet, B. Food waste matters-A systematic review of household food waste practices and their policy implications. J. Clean. Prod. 2018, 182, 978-991. [CrossRef]

22. Lanfranchi, M.; Calabrò, G.; De Pascale, A.; Fazio, A.; Giannetto, C. Household food waste and eating behavior: Empirical survey. Br. Food J. 2016, 118, 3059-3072. [CrossRef]

23. Neff, R.; Spiker, M.; Truant, P. Wasted food: US consumers' reported awareness, attitudes, and behaviors. PLoS ONE 2015, 10, e0127881. [CrossRef] [PubMed]

24. Qi, D.; Roe, B. Household food waste: Multivariate regression and principal components analyses of awareness and attitudes among US consumers. PLoS ONE 2016, 11, e0159250. [CrossRef] [PubMed]

25. Visschers, V.H.; Wickli, N.; Siegrist, M. Sorting out food waste behaviour: A survey on the motivators and barriers of self-reported amounts of food waste in households. J. Environ. Psychol. 2016, 45, 66-78. [CrossRef]

26. Direção Geral de Saúde. React Covid Inquérito Sobre Alimentação e Atividade Física em Contexto de Contenção Social. 2020. Available online: https:/www.dgs.pt/programa-nacional-para-a-promocao-da-atividade-fisica/ ficheiros-externos-pnpaf/rel_resultados-survey-covid-19-pdf.aspx (accessed on 30 July 2020).

27. Cappellini, B. The sacrifice of re-use: The travels of leftovers and family relations. J. Consum. Behav. 2009, 8, 365-375. [CrossRef]

28. Cappellini, B.; Parsons, E. Practising thrift at dinnertime: Mealtime leftovers, sacrifice and family membership. Sociol. Rev. 2012, 60, 121-134. [CrossRef]

29. Porpino, G.; Parente, J.; Wansink, B. Food waste paradox: Antecedents of food disposal in low income households. Int. J. Consum. Stud. 2015, 39, 619-629. [CrossRef]

30. Simunek, J.; Derflerova-Brazdova, Z.; Vitu, K. Food wasting: A study among Central European four-member families. Int. Food Res. J. 2015, 22, 2679-2683.

31. Abeliotis, K.; Lasaridi, K.; Costarelli, V.; Chroni, C. The implications of food waste generation on climate change: The case of Greece. Sustain. Prod. Consum. 2015, 3, 8-14. [CrossRef]

32. Wrap, W. Household Food and Drink Waste in the UK; Report Prepared by WRAP; WRAP: Banbury, UK, 2009. 
33. Quested, T.; Marsh, E.; Stunell, D.; Parry, A.D. Spaghetti soup: The complex world of food waste behaviours. Resour. Conserv. Recycl. 2013, 79, 43-51. [CrossRef]

Publisher's Note: MDPI stays neutral with regard to jurisdictional claims in published maps and institutional affiliations.

(C) 2020 by the authors. Licensee MDPI, Basel, Switzerland. This article is an open access article distributed under the terms and conditions of the Creative Commons Attribution (CC BY) license (http://creativecommons.org/licenses/by/4.0/). 